\title{
Left out but not forgotten: Should closer attention be paid to coinfection with herpes simplex virus type 1 and HIV?
}

\author{
Darrell H S Tan MD FRCPC, Rupert Kaul MD FRCPC PhD, Sharon Walsmley MD FRCPC MSC
}

DHS Tan, R Kaul, S Walsmley. Left out but not forgotten: Should closer attention be paid to coinfection with herpes simplex virus type 1 and HIV? Can J Infect Dis Med Microbiol 2009;20(1):e1-e7.

Herpes simplex virus type 1 (HSV-1) and type 2 (HSV-2) are among the most common coinfections seen in individuals infected with HIV-1. Most research on HSV-HIV coinfection has focused on HSV-2, and in particular, on its impact on HIV transmission. HSV-2 is associated with micro- and macroulcerations in genital mucosal surfaces, increased numbers of HIV target cells in genital mucosal tissue and increases in plasma HIV viral load of up to $0.5 \log _{10}$ copies/mL, such that HSV-2 infection increases the risk of both HIV acquisition and transmission. Because plasma HIV RNA levels are a major determinant of rates of CD4 cell decline, HSV-2 coinfection may also adversely affect the progression of HIV disease. Anti-HSV medications have in fact been associated with reciprocal decreases in HIV viral load in short-term studies. These findings have led to the development of several clinical trials of HSV-2 suppression as strategies for preventing HIV transmission and slowing the rate of HIV disease progression. HSV-1 coinfection has largely been ignored from this growing body of research, yet there are several reasons that this coinfection remains an important issue for study. First, the seroprevalence of HSV-1 is consistently higher than that of HSV-2 among both HIV-infected and HIV-uninfected populations, underscoring the relevance of HSV-1 coinfection to the majority of HIV-infected persons. Second, pre-existing HSV-1 antibodies in individuals may modulate the course of subsequently acquired HSV-2 infection; the implications of such changes on HSV-HIV coinfection remain unexplored. Third, HSV-1 and HSV-2 are closely related viruses that share $83 \%$ genetic homology. Their virological and pathobiological similarities suggest that their implications on HIV pathogenesis may be similar as well. Finally, HSV-1 is becoming increasingly relevant because the incidence of genital HSV-1 has risen. Although genital herpes is traditionally associated with HSV-2, recent studies have shown that the majority of serologically confirmed primary genital herpes in some settings is attributable to HSV-1. Because the genital tract is an important site of biological interaction between HSV and HIV, this epidemiological change may be clinically important.

Key Words: Coinfection; Genital herpes; HIV; HSV; Orolabial herpes
$\mathrm{H}$ erpes simplex virus type 1 (HSV-1) and type 2 (HSV-2) are among the most common coinfections seen in individuals infected with HIV-1, with prevalence rates of $90 \%$ to $100 \%$ and $52 \%$ to $95 \%$, respectively, worldwide (1-7). In comparison, the prevalence of HSV-1 and HSV-2 in the general population is considerably lower, at roughly $70 \%$ to $100 \%$ and $6 \%$ to $50 \%$, respectively $(8,9)$. The incidence of HSV-2 is also higher in HIV-infected populations, estimated at 18 to 74 per

\author{
Mise de côté sans être oubliée : Faut-il porter \\ davantage attention à la co-infection par le \\ VHS-1 et le VIH?
}

Les virus de l'herpès simplex de type 1 (VHS-1) et de type 2 (VHS-2) causent certaines des co-infections les plus souvent observées chez les sujets VIH-1 positifs. La majeure partie des recherches qui ont porté sur la co-infection VHS-VIH se sont attardées au VHS-2 et plus particulièrement à son impact sur la transmission du VIH. Le VHS-2 est associé à des micro- et des macro-ulcérations de la muqueuse génitale, à un nombre accru de cellules cibles du VIH dans les tissus de la muqueuse génitale et à des augmentations de la charge virale plasmatique du VIH jusqu'à $0,5 \log 10$ copie $/ \mathrm{mL}$, de sorte que l'infection au VHS-2 accroît le risque de contracter et de transmettre le VIH. Étant donné que le taux d'ARN du VIH est un important facteur déterminant du déclin des lymphocytes CD4, la co-infection par le VHS-2 peut aussi accélérer la progression de la maladie au VIH. Les médicaments anti-VHS ont en fait été associés à des baisses réciproques de la charge virale du VIH lors d'études à court terme. Ces résultats ont conduit à la mise au point de plusieurs études cliniques sur la suppression du VHS-2 comme stratégie pour prévenir la transmission du VIH et ralentir la progression de la maladie qu'il cause. La co-infection par le VHS-1 a pour une bonne part été ignorée de ce corpus de recherche croissant et pourtant, à plusieurs points de vue, cette co-infection demeure une importante question à explorer. Tout d'abord, la séroprévalence du VHS-1 est toujours plus élevée que celle du VHS-2, tant chez les populations infectées par le VIH que chez les populations indemnes, ce qui rappelle la portée de la co-infection par le VHS-1 chez la majorité des personnes infectées par le VIH. Ensuite, la préexistence d'anticorps anti-VHS-1 chez les sujets pourrait influer sur l'évolution de l'infection au VHS-2 acquise par la suite. Les implications de ces changements sur la co-infection VHS-VIH restent méconnues. Troisièmement, le VHS-1 et le VHS-2 sont des virus étroitement apparentés qui partagent $83 \%$ d'homologie génétique. Leurs similitudes virologiques et pathobiologiques donnent à penser que leurs implications dans la pathogenèse du VIH pourraient également être similaires. En terminant, le VHS-1 est de plus en plus pertinent en raison de l'augmentation de l'incidence du VHS-1 génital. Bien que l'herpès génital ait traditionnellement été associé au VHS-2, de récentes études ont montré que dans certains milieux, la majorité des cas d'herpès génital primaire confirmés par des analyses sérologiques est causée par le VHS-1. Étant donné que les voies génitales sont un important siège d'interaction biologique entre le VHS et le VIH, cette variation épidémiologique pourrait revêtir une importance clinique certaine.

1000 person-years versus 8.4 per 1000 person-years $(7,10,11)$. Both HSV-2 and HSV-1 are enveloped DNA viruses that cause lifelong incurable infections. The course of disease is characterized by periodic reactivations that can be either symptomatic outbreaks of vesicular, pustular and/or ulcerative lesions in the oral, genital or anal areas, or episodes of asymptomatic viral shedding, in which there is microbiological evidence of ongoing viral replication at the usually affected mucosa or skin 
in the absence of active herpes lesions (12-14). The frequency of asymptomatic shedding may partially explain why up to $90 \%$ of persons with serological evidence of HSV-2 deny any history of herpes symptoms (15).

The lifelong, often asymptomatic nature, and the high prevalence and incidence of HSV infection in HIV-positive individuals imply that any adverse impact of HSV on the natural history of HIV infection could have considerable clinical and public health significance. To date, most research on HSVHIV coinfection has focused on HSV-2, and in particular, on its impact on HIV transmission. HSV-1 coinfection has been largely ignored from this growing body of research, yet there are several reasons that this coinfection remains an important issue for study, including the high seroprevalence of HSV-1 relative to HSV-2, the modulatory impact of pre-existing HSV-1 antibodies on subsequent HSV-2 infection, the virological and pathophysiological similarities between the two viruses, and the increasing proportion of genital herpes that is caused by HSV-1. The relatively recent advent of type-specific serological assays that can distinguish between HSV-1 and HSV-2 has provided a timely technological advance that makes the conduct of such studies feasible. These assays detect human immunoglobulin $G$ ( $\lg G$ ) antibodies to glycoprotein G-1 (in HSV-1) or G-2 (in HSV-2) - the major proteins that evoke type-specific responses. In cohorts of pregnant women and sexually active adults, the often-used HerpeSelect 1 and 2 ELISA IgG (Focus Diagnostics, USA) and HerpeSelect 1 and 2 Immunoblot IgG (Focus Diagnostics, USA) have shown sensitivities of $91 \%$ to $100 \%$ and $89 \%$ to $100 \%$ for HSV-1 and HSV-2, respectively, and specificities of $92 \%$ to $95 \%$ and $94 \%$ to $98 \%$, respectively, compared with Western blot (16-18). The present paper reviews current evidence regarding the significance of HSV-2 in the transmission and pathogenesis of HIV infection, outlines the reasons that HSV-1 coinfection warrants increased attention in this area and identifies future areas for research.

\section{HOW HSV-2 MAY FUEL THE HIV EPIDEMIC}

It has long been recognized that 'classic' sexually transmitted infections (STIs) may be important cofactors in the propagation of HIV infection, and several randomized controlled trials of various STI management strategies for preventing HIV have been previously reported (19-22). These studies met with mixed success, and a number of plausible explanations have been advanced to explain the differences in their results, most notably, the important epidemiological differences among the HIV epidemics in the trial settings $(23,24)$. Importantly, however, these trials focused largely on bacterial STIs; the high burden of untreated HSV-2 infection in the study cohorts may have been another important reason that some trials failed to impact on HIV transmission rates. Since that time, a large number of studies have shown that HSV-2 seropositivity increases the risk of HIV acquisition, with one systematic review (25) showing an RR of 2.1 (95\% CI 1.4 to 3.2). Similar results were obtained in another, more recent meta-analysis (26), in which the RR of HIV associated with HSV-2 infection was considered separately for men (summary adjusted RR 2.7, 95\% CI 1.9 to 3.9), women (RR 3.1, 95\% CI 1.7 to 5.6) and among men who have sex with men ([MSM] RR 1.7, 95\% CI 1.2 to 2.4$)$.
The mechanisms through which HSV-2 may drive the amplification of HIV transmission are multiple (27). First, both symptomatic and asymptomatic HSV-2 infections may result in the disruption of the epithelial barrier of genital mucosal surfaces, providing increased portals of entry for HIV into the HSV-2-infected person during sexual contact. Second, HSV-2 infection results in increased recruitment of HIV target cells, such as CD4/CCR5 $\mathrm{T}$ lymphocytes and dendritic cells harbouring the lectin dendritic cell-specific intercellular adhesion molecule-3-grabbing nonintegrin, even in the absence of clinical symptoms or asymptomatic viral shedding (28). Higher numbers of target cells likely contribute to the increased HIV susceptibility observed in HSV-2-infected persons. Finally, among individuals who become HSV-2-HIV coinfected, HSV-2 has been associated with increases in HIV viral load in both plasma and genital secretions of up to $0.5 \log _{10}$ copies $/ \mathrm{mL}$ (12,29-32), thus increasing the likelihood of secondary HIV transmission to HIV-uninfected partners. Taken together, these findings provide a strong epidemiological and pathophysiological rationale for studying pharmacological HSV-2 suppression as a therapeutic strategy for preventing HIV acquisition. However, two recent randomized controlled trials $(33,34)$ conducted in HIV-endemic settings in East Africa have shown that acyclovir $400 \mathrm{mg}$ administered twice a day, compared against placebo, does not protect against HIV acquisition among HSV-2-seropositive individuals. These surprising findings are further discussed below.

\section{EVIDENCE THAT HSV-2 INFECTION MAY IMPACT ON HIV PROGNOSIS}

In addition to the role of HSV-2 in fuelling HIV transmission, it has more recently been recognized that HSV-2 may also have important adverse impacts on HIV disease progression for coinfected persons themselves. As mentioned above, both symptomatic and asymptomatic episodes of HSV-2 reactivation are associated with increases in HIV viral load of up to $0.5 \log _{10}$ copies $/ \mathrm{mL}$, which is recognized as a clinically significant amount (35). HSV-2 is believed to be the cause, not the effect, of increased HIV viral load, for several reasons. First, in vitro research shows that HSV gene products, such as infected cell protein (ICP)-0, ICP-4, ICP-27 and Us11, directly upregulate HIV replication (36-39), and that HSV increases expression of HIV in infected macrophages through stimulation of the nuclear factor-kappa B pathway (40). The release of proinflammatory cytokines from HSV-infected cells could similarly stimulate HIV expression, as has been observed for other herpesviruses (41). Second, HSV coinfection may result in the effective expansion of HIV cell tropism by modulating the expression of either CD4 or CCR5/CXCR4 coreceptors on their surfaces, as has been observed for human herpesvirus- 6 $(42,43)$. Simultaneous infection of host cells by both HIV and HSV could also expand and enhance the range of HIVsusceptible cells by producing viral 'pseudotypes' in which HIV genomes are encapsulated by HSV glycoproteins, resulting in productive HIV infection of CD4-negative cells (39). Indeed, this has been demonstrated for HSV-1; skin biopsy specimens coinfected with HSV-1, and HIV obtained from AIDS patients, have revealed HIV virions within keratinocytes - a cell type that is normally incapable of being infected by HIV due to the lack of CD4 receptors (44). Third, both the 
TABLE 1

Herpes simplex virus (HSV) type-specific seroprevalence among HIV-infected and HIV-mixed status populations

\begin{tabular}{|c|c|c|c|c|c|c|}
\hline \multirow[b]{2}{*}{ Reference } & \multirow[b]{2}{*}{ Setting } & \multirow[b]{2}{*}{ HIV status of cohort } & \multicolumn{3}{|c|}{ Seroprevalence, \% } & \multirow{2}{*}{$\begin{array}{c}\text { Proportion of HSV-2 positive } \\
\text { with HSV-1 coinfection, } \%\end{array}$} \\
\hline & & & HSV-1 & HSV-2 & HSV-1 and HSV-2 & \\
\hline van Benthem et al, 2001 (2) & Europe & Positive & 76.1 & 42.0 & 29.7 & 70.7 \\
\hline Romanowski et al, 2007 (6) & Canada & Positive & 78.0 & 54.5 & 42.1 & 77.3 \\
\hline Ameli et al, 2006 (57) & USA & Positive & 95.5 & 94.6 & 70.2 & 74.2 \\
\hline Smit et al, 2007 (53) & Amsterdam & Positive and negative & 65.3 & 41.1 & 30.2 & 73.5 \\
\hline
\end{tabular}

breadth and magnitude of HIV-specific CD8+ T cell proliferative and interferon-gamma responses are reduced in HSV-2HIV-coinfected persons, suggesting a potential mechanism through which this coinfection impairs the immune response to HIV and facilitates ongoing viral replication (45). Furthermore, the severity of symptomatic HSV disease in the setting of HIV infection is known to correlate with immune dysregulation (ie, low CD4 counts) rather than with HIV viremia $(12,46)$. Finally, treatment with anti-HSV medications, such as the acyclovir prodrug, valacyclovir, has been associated with reciprocal decreases in HIV viral load of $0.33 \log _{10}$ copies $/ \mathrm{mL}$ to $0.53 \log _{10}$ copies $/ \mathrm{mL}$ in small, randomized clinical trials $(47,48)$ with short periods of follow-up.

This causal relationship between HSV-2 and increased HIV viral load is important because plasma HIV viral load is the principal driver of immune depletion (as measured by CD4 cell decline) and HIV disease progression (49-51), such that patients with higher viral loads have faster rates of progression to AIDS and death. It follows that HSV-2 coinfection may be associated with more rapid progression of HIV disease, but this question has yet not been directly studied.

\section{HSV-1: \\ AN UNJUSTLY IGNORED COPATHOGEN?}

HSV-1 is capable of causing severe morbidity and mortality, both in the setting of advanced HIV disease (52) and in immunocompetent hosts. Furthermore, HIV has been shown to be independently associated with both HSV-1 (OR 1.10, 95\% CI 1.02 to 1.1 ) and HSV-2 (OR 1.50, 95\% CI 1.37 to 1.68 ) infections in large cohort studies (53). Studies have also shown a trend toward more subclinical shedding of HSV-1 in HIV-infected versus HIV-uninfected persons (12). Yet, current research into HSVHIV coinfection has all but ignored HSV-1, in part because it is generally understood to cause less frequent and less severe herpes reactivations than HSV-2 $(54,55)$. In addition, because coinfection with HSV-1 and HSV-2 is common, it may be difficult to separate the impact of HSV-1 coinfection with HIV from that of HSV-2 coinfection. Nevertheless, the frequency of HSV-1, its impact on subsequent HSV-2, its biological similarities to HSV-2 and the proportion of genital herpes caused by HSV-1 all suggest its potential importance both with regard to the transmission of HIV to HIV-susceptible persons and the pathogenesis of HIV disease in HIV-infected persons.

\section{HSV-1 is common}

The seroprevalence of HSV-1 is consistently higher than that of HSV-2 worldwide, because the acquisition of this infection generally occurs in childhood through direct person-to-person contact. Roughly $50 \%$ to $70 \%$ of individuals in most industrialized world settings, and up to $99 \%$ to $100 \%$ in adult Sub-Saharan African populations have been infected with this ubiquitous virus (9). In the setting of HIV, the prevalence is still higher, underscoring the relevance of HSV-1 coinfection to the majority of HIV-infected persons. Paradoxically, the near-universal seroprevalence of HSV-1 in settings with high HIV endemicity is a major reason that this virus has been ignored in much of the literature to date; it becomes virtually impossible to accrue sufficient HSV-1-negative persons to serve as a control group in such settings.

In this regard, the later age of infection of HSV-1 and corresponding high seroincidence of HSV-1 infection reported in HIV high-risk populations in some industrialized countries is an emerging phenomenon of epidemiological importance that may provide important opportunities to explore the significance of HSV-1-HIV coinfection. For instance, among participants in a large Australian cohort study (56) of MSM who were HIVnegative at baseline, the observed incidence rates for HSV-1 was 5.58 per 100 person-years, compared with 1.45 per 100 personyears for HSV-2. The HSV-1 incidence rate was highest among men younger than 25 years of age (11.48 per 100 person-years), but remained higher than the overall HSV-2 incidence rate even among those in the oldest age category studied (2.49 per 100 person-years for those older than 44 years of age) (56). Although the relationship between HSV and HIV incidence rates was not reported, these findings suggest that HIV prevention strategies targeting HSV coinfection must increasingly consider the impact of both prevalent and incident HSV-1.

An additional way in which the high prevalence of HSV-1 may be epidemiologically relevant to studies of HSV-HIV coinfection stems from the observation that the majority of persons with HSV-2 infection are coinfected with HSV-1. Studies $(2,6,53,57)$ of HSV seroprevalence in HIV-positive or HIVmixed status populations have shown remarkable consistency in the proportion of HSV-2-infected persons who harbour HSV-1 coinfection, at roughly $70 \%$ to $75 \%$ (Table 1). It is, therefore, conceivable that some of the reported adverse impact of HSV-2 coinfection among HIV-infected persons may be driven by or exacerbated by the presence of HSV-1 coinfection. It is unlikely that HSV-1 infection itself could explain these effects, because the HSV-2 seronegative control groups against whom HSV-2infected persons are compared in such studies would be expected to have a high burden of HSV-1 infection. Nevertheless, the possibility that dual infection with both HSV types is at least in part responsible for the outcomes attributed to HSV-2 infection warrants further consideration.

HSV-1 may modulate the course of incident HSV-2 infection A related reason that dual infection with HSV-1 and HSV-2 may be important is because pre-existing HSV-1 infections have been shown to modulate the course of HSV-2 infection. Studies have shown both decreases and increases in various measures of HSV-2 severity. For instance, although pre-existing antibodies against HSV-1 do not diminish the likelihood of 
acquiring HSV-2 infection, they do increase the likelihood that incident HSV-2 infection will be asymptomatic by a factor of $2.6(\mathrm{P}<0.001)$ (58). Conversely, compared with HSV-2 infection alone, dual infection with both HSV types has also been shown to result in increased HSV-2 shedding among HIVinfected persons, with an OR of 1.9 (95\% CI 1.0 to 3.7) (12).

Such modulations of HSV-2 severity in those with preexisting HSV-1 antibodies may be particularly important given the above-mentioned later age of HSV-1 seroincidence in some settings (56), because an increasing proportion of individuals may be expected to acquire primary HSV-2 infection (ie, incident HSV-2 in the absence of prior HSV-1 antibodies). One study (10) reported that incident HSV-2 infection in recently HIV-infected individuals was not associated with significant changes in HIV viral load or CD4 cell count levels, but pre-existing HSV-1 serology was not documented. Most incident cases of HSV-2 infection in that study likely had preexisting HSV-1 antibodies, because nine of 10 cases were asymptomatic. The impact of primary incident HSV-2 infection on HIV pathogenesis and transmissibility thus remain undetermined and, therefore, further attention to HSV-1 serological status in HSV-HIV-coinfection studies is needed.

\section{$\mathrm{HSV}-1$ is similar to HSV-2}

Another reason that HSV-1 merits further attention is that HSV-1 and HSV-2 are closely related herpesviruses that share $83 \%$ genetic homology (59). Furthermore, most of their divergent nucleotide sequences occur in noncoding regions of their genomes (59). This high degree of genetic homology is mirrored by the pathophysiological similarities between HSV types, and together these observations suggest that the clinical implications of HSV-1 and HSV-2 on HIV pathogenesis may be similar as well (39).

In support of this possibility, numerous in vitro experiments have shown that HSV-1 gene products can upregulate HIV expression, as mentioned above $(36-40,60)$. Indeed, in contrast to the clinical literature on HSV-HIV coinfection, the majority of basic science literature on the molecular mechanisms of HSV-HIV interactions has focused on HSV-1, largely because of a greater availability of HSV-1 laboratory strains and animal models. Nearly all HSV-1 genes have an HSV-2 homologue, such that these basic science findings regarding HSV-1 have been extrapolated to HSV-2 in the clinical setting. Thus, because of the close relatedness of the two virus types, both HSV-1 and HSV-2 have been shown to increase HIV replication. For instance, coincubation of peripheral blood mononuclear cells from HIV-infected donors with either HSV-1 or HSV-2 has been demonstrated to produce active HIV-1 replication (61). The mechanism of this effect is thought to be through both mitogenic stimulation of the HIV-infected cells as well as transactivation of proviral HIV by HSV gene products. Similarly, other investigators have shown that coincubation of resting CD4+ T cells from HIV-infected patients with supernatants from monocyte-derived macrophages that had been exposed to HSV-1 or HSV-2 virions results in HIV replication (62). This effect was not seen after treating resting CD4+ T cells with only HSV virions, nor with only the supernatants of unconditioned monocyte-derived macrophages.

HSV-1 accounts for an increasing burden of genital herpes In general, genital shedding of HSV-2 is higher than that of HSV-1, and oral shedding of HSV-1 is higher than that of
HSV-2 (63). However, the issue of HSV type is becoming especially relevant because the incidence of genital HSV-1 has increased. For instance, a Swedish study (64) showed that 44\% of 97 patients presenting with culture-positive primary genital herpes have HSV-1 infection, and that $64 \%$ of serologically confirmed primary genital herpes was attributable to HSV-1. In Edinburgh, Scotland (United Kingdom), HSV-1 accounted for $42 \%$ and $62 \%$ of virologically confirmed first episode genital herpes outbreaks in men and women, respectively (65). Among American college students, the proportion of newly diagnosed genital herpes attributed to HSV-1 rose dramatically from 31\% in 1993 to $78 \%$ in $2001(\mathrm{P}<0.001$; linear trend $\mathrm{P}<0.001)(66)$. Similarly, high or rising rates of genital HSV-1 have been shown in other industrialized settings, including France (67), Finland (68), Holland (53) and the United States $(69,70)$. In Northern Ireland, this shift has actually rendered HSV-1 the most common cause of recurrent genital ulcer disease among women attending genitourinary medicine clinics (71). As for HSV-2, asymptomatic shedding of genital HSV-1 has also been documented (72), and the impact of such shedding on HIV remains to be determined.

Because the genital tract is an important site of biological interaction between HSV and HIV, this epidemiological change may be clinically important. HSV-1-induced microand macroulceration of the genital mucosa would be expected to have similar implications for facilitating HIV transmission to those of HSV-2 lesions, as would the upregulation of HIV by HSV-1 through the molecular mechanisms described above. However, differences have been observed in the genital mucosal immune responses to HSV-1 and HSV-2 infections (73). For instance, HSV-1 productively infects mucosal dendritic cells and downregulates CD1a, CD40, ICAM-1, CD80 and CD86, potentially resulting in delayed $\mathrm{T}$ cell activation as a strategy of immune evasion (74). In contrast, HSV-2 induces activation of submucosal dendritic cells, which drain to local lymph nodes and stimulate $\mathrm{T}$ cell priming and interferongamma release by presenting viral peptides in the context of major histocompatibility complex class II molecules (75). The significance of such nuances in what is known about the immune responses to HSV-1 versus HSV-2 for HIV coinfection remain largely unexplored. One may speculate that different degrees of recruitment of HIV target cells to the genital tract may produce clinical variation in HSV-induced HIV susceptibility and pathogenesis. However, because symptomatic genital HSV-1 recurs less frequently than HSV-2 (one versus four times a year) $(54,55)$, the overall impact of this epidemiological shift remains to be determined.

\section{IMPLICATIONS FOR CLINICAL PRACTICE AND RESEARCH}

HSV-HIV coinfection may yield practical implications because the availability of safe, affordable anti-HSV medications (acyclovir, valacyclovir and famciclovir) makes this infection a potential locus for clinical and public health interventions. But there remain important unanswered questions regarding the ways in which emerging knowledge on HSV-1 and HSV-2 infection could inform clinical practice and public health policy.

In the clinical care of HIV-infected persons, highly active antiretroviral therapy (HAART) has drastically reduced the 
morbidity and mortality associated with HIV-1 (herein referred to as 'HIV') infection, and transformed an invariably fatal disease into a manageable, chronic condition. However, the inconvenience, cost, potential long- and short-term toxicities, and the risk of developing drug-resistant HIV associated with daily lifelong HAART makes the potential delay of HAART initiation an extremely desirable goal for HIV-infected individuals. Suppression of HSV coinfection may provide a novel therapeutic strategy for achieving this goal. Indeed, some authors $(76,77)$ have already suggested that all HSV-2-HIVcoinfected individuals receive chronic anti-HSV therapy with acyclovir or its prodrugs for this purpose, but clinical trial data in support of this recommendation are currently lacking. HSV-2 therapy may also be of benefit to individuals already using HAART, in whom adjunctive measures to improve the effectiveness of antiretroviral therapy are still needed. A small study (78) has suggested that HSV-2 shedding can persist even in the context of HAART use, but this finding requires confirmation before clinical trials of anti-HSV medications in this setting are further considered. In addition, based on the high seroprevalence of HSV-1, analogy to HSV-2 and emerging etiological role of HSV-1 in genital herpes, further research into the clinical significance of HSV-1 coinfection on the natural history of untreated and treated HIV infection is warranted. The more moderate seroprevalence and the relatively high seroincidence of HSV-1 among adults in industrialized compared with developing areas suggests that these are the settings in which such efforts will be most realistic. In addition, because modifiable risk factors, such as the use of hormonal contraceptives, have been shown to increase shedding of both HSV-1 and HSV-2 (79), the potential synergy between these factors with HSV suppression may warrant additional study.

In the context of HIV prevention, over two decades' worth of efforts to develop behavioural and biomedical interventions has yielded few successes, and the inability of chronic suppressive acyclovir to prevent HIV transmission in the two randomized controlled trials mentioned above may appear to only add to this litany of failures. However, several possible explanations have been advanced to explain these disappointing results, including the prevalence of other genital ulcer disease pathogens, inadequate drug adherence, inadequate statistical power and chance. Chief among the potential reasons, however, is the possibility that an inadequate dose of acyclovir was used.

\section{REFERENCES}

1. McFarland W, Gwanzura L, Bassett MT, et al. Prevalence and incidence of herpes simplex virus type 2 infection among male Zimbabwean factory workers. J Infect Dis 1999;180:1459-65.

2. van Benthem BH, Spaargaren J, van Den Hoek JA, et al. Prevalence and risk factors of HSV-1 and HSV-2 antibodies in European HIV infected women. Sex Transm Infect 2001;77:120-4.

3. Lama JR, Lucchetti A, Suarez L, et al. Association of herpes simplex virus type 2 infection and syphilis with human immunodeficiency virus infection among men who have sex with men in Peru. J Infect Dis 2006;194:1459-66.

4. Kapiga SH, Sam NE, Bang H, et al. The role of herpes simplex virus type 2 and other genital infections in the acquisition of HIV-1 among high-risk women in northern Tanzania. J Infect Dis 2007;195:1260-9.

5. Suligoi B, Dorrucci M, Volpi A, et al. Prevalence and determinants of herpes simplex virus type 2 infection in a cohort of HIV-positive individuals in Italy. Sex Transm Dis 2002;29:665-7.

6. Romanowski B, Myziuk L, Trottier S, et al. Seroprevalence of herpes simplex virus in patients infected with HIV in Canada. In: 17th International Society for Sexually Transmitted Diseases
Indeed, previous trials in which clinically important effects of herpesvirus suppression were seen in HIV-coinfected persons used either much higher doses of acyclovir, or the acyclovir prodrug valacyclovir. For instance, more than $3200 \mathrm{mg}$ of acyclovir taken per day was associated with improved survival in a meta-analysis of studies among advanced AIDS patients in the pre-HAART era (80), and $800 \mathrm{mg}$ of acyclovir taken twice daily produced decreases in cervicovaginal HIV shedding in HSV-2-HIV-coinfected women in Thailand (81). Valacyclovir may be preferable to study over acyclovir due to its improved bioavailability (54.5\% versus $15 \%$ to $30 \%$ ) and significantly decreased pill burden (82); indeed, among women in Burkina Faso (Africa) and MSM in Peru, $500 \mathrm{mg}$ of valacyclovir taken twice daily was associated with reductions in plasma HIV RNA levels of up to $0.53 \log _{10}$ copies/mL $(47,48)$. Furthermore, the finding that HSV-2-specific immune responses persist in genital skin long after resolution of clinical symptoms suggests that prolonged doses of such high-potency drugs may be required to fully suppress the effects of HSV-2 infection (83).

\section{CONCLUSION}

HSV-2-HIV coinfection has garnered appropriate attention in both HIV prevention and treatment, because of the welldocumented virological, clinical and epidemiological synergisms between these two viruses. However, more information on their interactions with HSV-1 is clearly needed to identify promising strategies for decreasing HIV transmission and attenuating HIV disease progression. In particular, increased attention to the significance of incident and prevalent HSV-1 infection on HIV pathogenesis, pre-existing HSV-1 antibodies in HIV-infected persons with incident HSV-2 infection, and the emergence of symptomatic and asymptomatic genital HSV-1 among HIV-infected and HIV-uninfected persons will be of value.

Published recommendations for type-specific HSV serological testing have cited both the high seroprevalence of HSV-1 and the paucity of published literature on genital HSV-1 infection as reasons for focusing exclusively on HSV-2 (84). We agree that additional work in this area is needed, but believe that the high seroprevalence of HSV-1 is, if anything, in fact one of several reasons for this need, rather than a reason for dismissing HSV-1 and its potential impact on both HIV transmission and pathogenesis.

Research/10th International Union against Sexually Transmitted Infections World Congress, P-243. Seattle, 2007.

7. Ramaswamy M, Sabin C, McDonald C, Smith M, Taylor C, Geretti AM. Herpes simplex virus type 2 (HSV-2) seroprevalence at the time of HIV-1 diagnosis and seroincidence after HIV-1 diagnosis in an ethnically diverse cohort of HIV-1-infected persons. Sex Transm Dis 2006;33:96-101.

8. Nahmias AJ, Lee FK, Beckman-Nahmias S. Sero-epidemiological and sociological patterns of herpes simplex virus infection in the world. Scand J Infect Dis 1990;69:19-36.

9. Smith JS, Robinson NJ. Age-specific prevalence of infection with herpes simplex virus types 2 and 1: A global review. J Infect Dis 2002;186(Suppl 1):S3-28.

10. Cachay ER, Frost SDW, Poon AFY, et al. Herpes simplex virus type 2 acquisition during recent HIV infection does not influence plasma HIV levels. J Acquir Immune Defic Syndr 2008;47:592-6.

11. Armstrong GL, Schillinger J, Markowitz L, et al. Incidence of herpes simplex virus type 2 infection in the United States. Am J Epidemiol 2001;153:912-20. 
12. Schacker T, Zeh J, Hu HL, Hill E, Corey L. Frequency of symptomatic and asymptomatic herpes simplex virus type 2 reactivations among human immunodeficiency virus-infected men. J Infect Dis 1998;178:1616-22.

13. Augenbraun M, Feldman J, Chirgwin K, et al. Increased genital shedding of herpes simplex virus type 2 in HIV-seropositive women. Ann Intern Med 1995;123:845-7.

14. Wald A, Huang ML, Carrell D, Selke S, Corey L. Polymerase chain reaction for detection of herpes simplex virus (HSV) DNA on mucosal surfaces: Comparison with HSV isolation in cell culture. J Infect Dis 2003;188:1345-51.

15. Fleming DT, McQuillan GM, Johnson RE, et al. Herpes simplex virus type 2 in the United States, 1976 to 1994. N Engl J Med 1997;337:1105-11.

16. Ashley RL. Sorting out the new HSV type specific antibody tests. Sex Transm Infect 2001;77:232-7.

17. Wald A, Ashley-Morrow R. Serological testing for herpes simplex virus (HSV)-1 and HSV-2 infection. Clin Infects Dis 2002;35:S173-82.

18. Strick L, Wald A. Type-specific testing for herpes simplex virus. Expert Rev Mol Diagn 2004:4:443-53.

19. Kamali A, Quigley M, Nakiyingi J, et al. Syndromic management of sexually-transmitted infections and behaviour change interventions on transmission of HIV-1 in rural Uganda: A community randomised trial. Lancet 2003;361:645-52.

20. Grosskurth H, Mosha F, Todd J, et al. Impact of improved treatment of sexually transmitted diseases on HIV infection in rural Tanzania: Randomised controlled trial. Lancet 1995;346:530-6.

21. Kaul R, Kimani J, Nagelkerke NJ, et al. Monthly antibiotic chemoprophylaxis and incidence of sexually transmitted infections and HIV-1 infection in Kenyan sex workers: A randomized controlled trial. JAMA 2004;291:2555-62.

22. Wawer MJ, Sewankambo NK, Serwadda D, et al. Control of sexually transmitted diseases for AIDS prevention in Uganda: A randomised community trial. Rakai Project Study Group. Lancet 1999;353:525-35.

23. Grosskurth H, Gray R, Hayes R, Mabey D, Wawer M. Control of sexually transmitted diseases for HIV-1 prevention: Understanding the implications of the Mwanza and Rakai trials. Lancet 2000;355:1981-7.

24. Korenromp EL, White RG, Orroth KK, et al. Determinants of the impact of sexually transmitted infection treatment on prevention of HIV infection: A synthesis of evidence from the Mwanza, Rakai, and Masaka intervention trials. J Infect Dis 2005;191(Suppl 1):S168-78.

25. Wald A, Link K. Risk of human immunodeficiency virus infection in herpes simplex virus type 2-seropositive persons: A meta-analysis. J Infect Dis 2002;185:45-52.

26. Freeman EE, Weiss HA, Glynn JR, Cross PL, Whitworth JA, Hayes RJ. Herpes simplex virus 2 infection increases HIV acquisition in men and women: Systematic review and meta-analysis of longitudinal studies. AIDS 2006;20:73-83.

27. Kaul R, Pettengell C, Sheth PM, et al. The genital tract immune milieu: An important determinant of HIV susceptibility and secondary transmission. J Reprod Immunol 2008;77:32-40.

28. Rebbapragada A, Wachihi C, Pettengell C, et al. Negative mucosal synergy between herpes simplex type 2 and HIV in the female genital tract. AIDS 2007;21:589-98.

29. Mole L, Ripich S, Margolis D, Holodniy M. The impact of active herpes simplex virus infection on human immunodeficiency virus load. J Infect Dis 1997;176:766-70.

30. Schacker T, Ryncarz AJ, Goddard J, Diem K, Shaughnessy M, Corey L. Frequent recovery of HIV-1 from genital herpes simplex virus lesions in HIV-1-infected men. JAMA 1998;280:61-6.

31. Baeten JM, McClelland RS, Corey L, et al. Vitamin A supplementation and genital shedding of herpes simplex virus among HIV-1-infected women: A randomized clinical trial. J Infect Dis 2004;189:1466-71.

32. McClelland RS, Wang CC, Overbaugh J, et al. Association between cervical shedding of herpes simplex virus and HIV-1. AIDS 2002;16:2425-30.

33. Celum C, Wald A, Hughes J, et al. Effect of aciclovir on HIV-1 acquisition in herpes simplex virus 2 seropositive women and men who have sex with men: A randomised, double-blind, placebocontrolled trial. Lancet 2008;371:2109-19.

34. Watson-Jones D, Weiss HA, Rusizoka M, et al. Effect of herpes simplex suppression on incidence of HIV among women in Tanzania. N Engl J Med 2008;358:1560-71.
35. Panel on Antiretroviral Guidelines for Adults and Adolescents. Guidelines for the use of antiretroviral agents in HIV-1-infected adults and adolescents. Department of Health and Human Services, 2008:1-139. <www.aidsinfo.nih.gov/ContentFiles/ AdultandAdolescentGL.pdf> (Version current at February 10, 2009).

36. Margolis DM, Rabson AB, Straus SE, Ostrove JM. Transactivation of the HIV-1 LTR by HSV-1 immediate-early genes. Virology 1992;186:788-91.

37. Kucera LS, Leake E, Iyer N, Raben D, Myrvik QN. Human immunodeficiency virus type 1 (HIV-1) and herpes simplex virus type 2 (HSV-2) can coinfect and simultaneously replicate in the same human CD4+ cell: Effect of coinfection on infectious HSV-2 and HIV-1 replication. AIDS Res Hum Retroviruses 1990;6:641-7.

38. Diaz JJ, Dodon MD, Schaerer-Uthurralt N, et al. Post-transcriptional transactivation of human retroviral envelope glycoprotein expression by herpes simplex virus Us11 protein. Nature 1996;379:273-7.

39. Palu G, Benetti L, Calistri A. Molecular basis of the interactions between herpes simplex viruses and HIV-1. Herpes 2001;8:50-5.

40. Moriuchi M, Moriuchi H, Williams R, Straus SE. Herpes simplex virus infection induces replication of human immunodeficiency virus type 1. Virology 2000;278:534-40.

41. Vicenzi E, Poli G. Regulation of HIV expression by viral genes and cytokines. J Leukoc Biol 1994;56:328-34.

42. Flamand L, Romerio F, Reitz MS, Gallo RC. CD4 promoter transactivation by human herpesvirus 6. J Virol 1998;72:8797-805.

43. Lusso P, De Maria A, Malnati M, et al. Induction of CD4 and susceptibility to HIV-1 infection in human CD8 + T lymphocytes by human herpesvirus 6. Nature 1991;349:533-5.

44. Heng MC, Heng SY, Allen SG. Co-infection and synergy of human immunodeficiency virus-1 and herpes simplex virus-1. Lancet 1994;343:255-8

45. Sheth PM, Sunderji S, Shin LYY, et al. Coinfection with herpes simplex virus type 2 is associated with reduced HIV-specific T cell responses and systemic immune activation. J Infect Dis 2008;197:1394-401.

46. Wright PW, Hoesley CJ, Squires KE, Croom-Rivers A, Weiss HL, Gnann JW Jr. A prospective study of genital herpes simplex virus type 2 infection in human immunodeficiency virus type 1 (HIV-1)seropositive women: Correlations with CD4 cell count and plasma HIV-1 RNA level. Clin Infect Dis 2003;36:207-11.

47. Zuckerman RA, Lucchetti A, Whittington WLH, et al. Herpes simplex virus (HSV) suppression with valacyclovir reduces rectal and blood plasma HIV-1 levels in HIV-1/HSV-2-seropositive men: A randomized, double-blind, placebo-controlled crossover trial. J Infect Dis 2007;196:1500-8.

48. Nagot N, Ouedraogo A, Foulongne V, et al. Reduction of HIV-1 RNA levels with therapy to suppress herpes simplex virus. N Engl J Med 2007;356:790-9.

49. Mellors JW, Munoz A, Giorgi JV, et al. Plasma viral load and CD4+ lymphocytes as prognostic markers of HIV-1 infection. Ann Intern Med 1997;126:946-54.

50. Mellors JW, Rinaldo CR Jr, Gupta P, White RM, Todd JA, Kingsley LA. Prognosis in HIV-1 infection predicted by the quantity of virus in plasma. Science 1996;272:1167-70.

51. Rodriguez B, Sethi AK, Cheruvu VK, et al. Predictive value of plasma HIV RNA level on rate of CD4 T-cell decline in untreated HIV infection. JAMA 2006;296:1498-506.

52. Moulignier A, Baudrimont M, Martin-Negrier ML, Mikol J, Lapresle C, Dupont B. Fatal brain stem encephalitis due to herpes simplex virus type 1 in AIDS. J Neurol 1996;243:491-3.

53. Smit C, Pfrommer C, Mindel A, et al. Rise in seroprevalence of herpes simplex virus type 1 among highly sexual active homosexual men and an increasing association between herpes simplex virus type 2 and HIV over time (1984-2003). Eur J Epidemiol 2007;22:937-44.

54. Lafferty WE, Coombs RW, Benedetti J, Critchlow C, Corey L. Recurrences after oral and genital herpes simplex virus infection. Influence of site of infection and viral type. N Engl J Med 1987;316:1444-9.

55. Engelberg R, Carrell D, Krantz E, Corey L, Wald A. Natural history of genital herpes simplex virus type 1 infection. Sex Transm Dis 2003;30:174-7.

56. Jin F, Prestage GP, Mao L, et al. Transmission of herpes simplex virus types 1 and 2 in a prospective cohort of HIV-negative gay men: The health in men study. J Infect Dis 2006;194:561-70. 
57. Ameli N, Bacchetti P, Morrow RA, et al. Herpes simplex virus infection in women in the WIHS: Epidemiology and effect of antiretroviral therapy on clinical manifestations. AIDS 2006;20:1051-8.

58. Langenberg AG, Corey L, Ashley RL, Leong WP, Straus SE. A prospective study of new infections with herpes simplex virus type 1 and type 2. Chiron HSV Vaccine Study Group. N Engl J Med 1999;341:1432-8.

59. Dolan A, Jamieson FE, Cunningham C, Barnett BC, McGeoch DJ. The genome sequence of herpes simplex virus type 2. J Virol 1998;72:2010-21.

60. Mosca JD, Bednarik DP, Raj NB, et al. Herpes simplex virus type-1 can reactivate transcription of latent human immunodeficiency virus. Nature 1987;325:67-70.

61. Tremblay M, Gornitsky M, Wainberg MA. Active replication of human immunodeficiency virus type 1 by peripheral blood mononuclear cells following coincubation with herpes viruses. J Med Virol 1989;29:109-14.

62. Moriuchi M, Moriuchi $\mathrm{H}$. In vitro reactivation of HIV-1 by stimulation with herpes simplex virus infection. Sex Transm Dis 2002;29:308-9.

63. Wald A, Ericsson M, Krantz E, Selke S, Corey L. Oral shedding of herpes simplex virus type 2. Sex Transm Infect 2004;80:272-6. (Erratum in 2004;80:546).

64. Lowhagen GB, Bergbrant IM, Bergstrom T, Ryd W, Voog E. PCR detection of Epstein-Barr virus, herpes simplex virus and human papillomavirus from the anal mucosa in HIV-seropositive and HIVseronegative homosexual men. Int J STD AIDS 1999;10:615-8.

65. Manavi K, McMillan A, Ogilvie M. Herpes simplex virus type 1 remains the principal cause of initial anogenital herpes in Edinburgh, Scotland. Sex Transm Dis 2004;31:322-4.

66. Roberts CM, Pfister JR, Spear SJ. Increasing proportion of herpes simplex virus type 1 as a cause of genital herpes infection in college students. Sex Transm Dis 2003;30:797-800.

67. Janier M, Scieux C, Meouchi R, et al. Virological, serological and epidemiological study of 255 consecutive cases of genital herpes in a sexually transmitted disease clinic of Paris (France): A prospective study. Int J STD AIDS 2006;17:44-9.

68. Kortekangas-Savolainen O, Vuorinen T. Trends in herpes simplex virus type 1 and 2 infections among patients diagnosed with genital herpes in a Finnish sexually transmitted disease clinic, 1994-2002. Sex Transm Dis 2007;34:37-40.

69. Xu F, Sternberg MR, Kottiri BJ, et al. Trends in herpes simplex virus type 1 and type 2 seroprevalence in the United States. JAMA 2006;296:964-73.

70. Lafferty WE, Downey L, Celum C, Wald A. Herpes simplex virus type 1 as a cause of genital herpes: Impact on surveillance and prevention. J Infect Dis 2000;181:1454-7.
71. Coyle PV, O'Neill HJ, Wyatt DE, McCaughey C, Quah S, McBride MO. Emergence of herpes simplex type 1 as the main cause of recurrent genital ulcerative disease in women in Northern Ireland. J Clin Virol 2003;27:22-9.

72. Kim HN, Meier A, Huang M-L, et al. Oral herpes simplex virus type 2 reactivation in HIV-positive and -negative men. J Infect Dis 2006;194:420-7.

73. MasCasullo V, Fam E, Keller MJ, Herold BC. Role of mucosal immunity in preventing genital herpes infection. Viral Immunol 2005; 18:595-606.

74. Mikloska Z, Bosnjak L, Cunningham AL. Immature monocytederived dendritic cells are productively infected with herpes simplex virus type 1. J Virol 2001;75:5958-64.

75. Linehan MM, Richman S, Krummenacher C, Eisenberg RJ, Cohen $\mathrm{GH}$, Iwasaki A. In vivo role of nectin-1 in entry of herpes simplex virus type 1 (HSV-1) and HSV-2 through the vaginal mucosa. J Virol 2004;78:2530-6.

76. Strick LB, Wald A, Celum C. Management of herpes simplex virus type 2 infection in HIV type 1-infected persons. Clin Infect Dis 2006;43:347-56.

77. Sexually transmitted diseases treatment guidelines 2002. Centers for Disease Control and Prevention. MMWR Recomm Rep 2002;51:1-78.

78. Posavad CM, Wald A, Kuntz S, et al. Frequent reactivation of herpes simplex virus among HIV-1-infected patients treated with highly active antiretroviral therapy. J Infect Dis 2004;190:693-6.

79. Mostad SB, Kreiss JK, Ryncarz AJ, et al. Cervical shedding of herpes simplex virus in human immunodeficiency virus-infected women: Effects of hormonal contraception, pregnancy, and vitamin A deficiency. J Infect Dis 2000;181:58-63.

80. Ioannidis JP, Collier AC, Cooper DA, et al. Clinical efficacy of high-dose acyclovir in patients with human immunodeficiency virus infection: A meta-analysis of randomized individual patient data. J Infect Dis 1998;178:349-59.

81. Dunne E, Whitehead S, Sternberg M, et al. The effect of suppressive acyclovir therapy on HIV cervicovaginal shedding in HIV - and HSV-2-infected women, Chiang Rai, Thailand. The 14th Conference on Retroviruses and Opportunistic Infections. Los Angeles, February 25-28, 2007.

82. MacDougall C, Guglielmo BJ. Pharmacokinetics of valaciclovir. J Antimicrob Chemother 2004;53:899-901.

83. Zhu J, Koelle DM, Cao J, et al. Virus-specific CD8+ T cells accumulate near sensory nerve endings in genital skin during subclinical HSV-2 reactivation. J Exp Med 2007;204:595-603.

84. Guerry SL, Bauer HM, Klausner JD, et al. Recommendations for the selective use of herpes simplex virus type 2 serological tests. Clin Infect Dis 2005;40:38-45. 


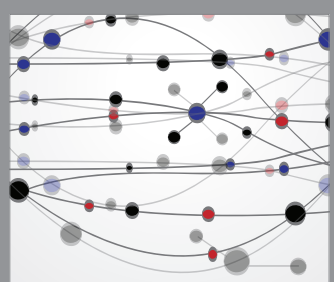

The Scientific World Journal
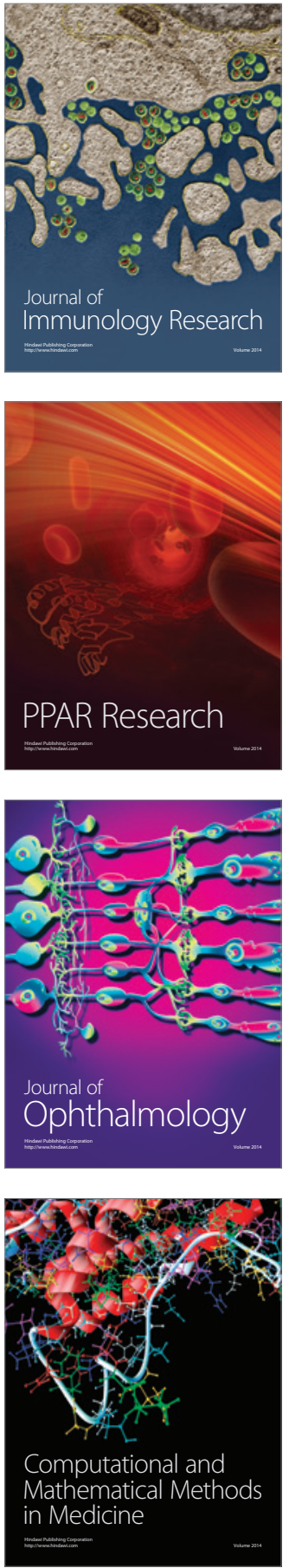

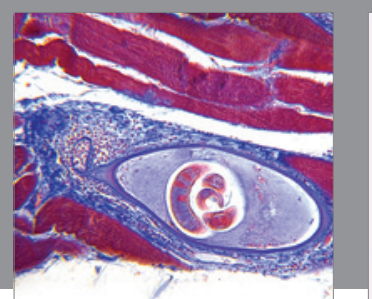

Gastroenterology Research and Practice

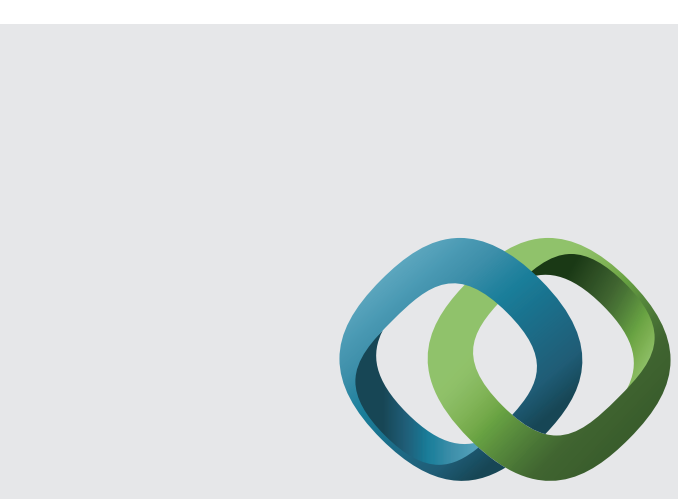

\section{Hindawi}

Submit your manuscripts at

http://www.hindawi.com
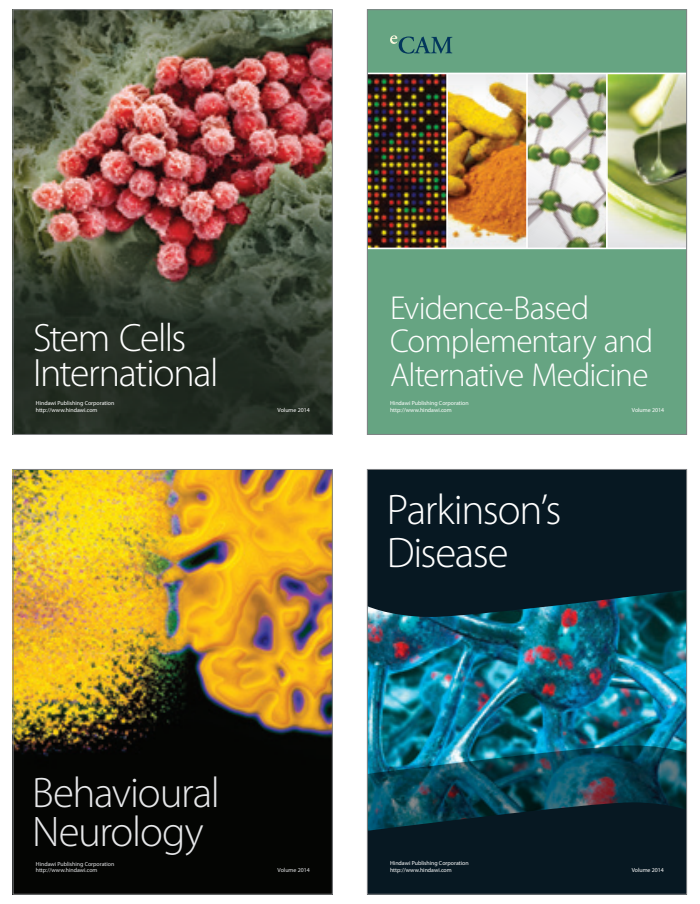
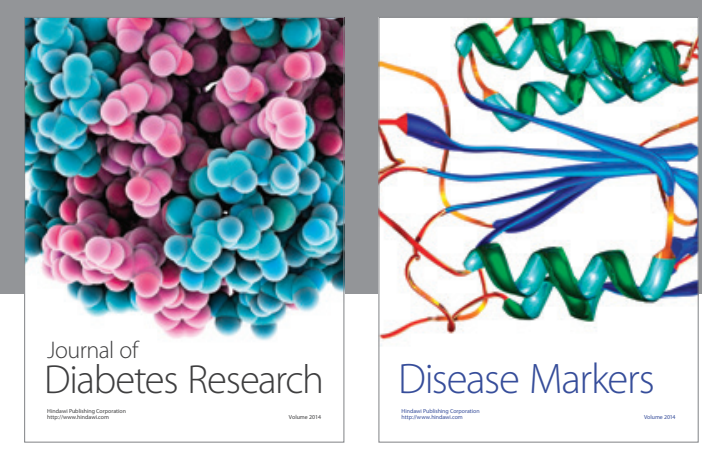

Disease Markers
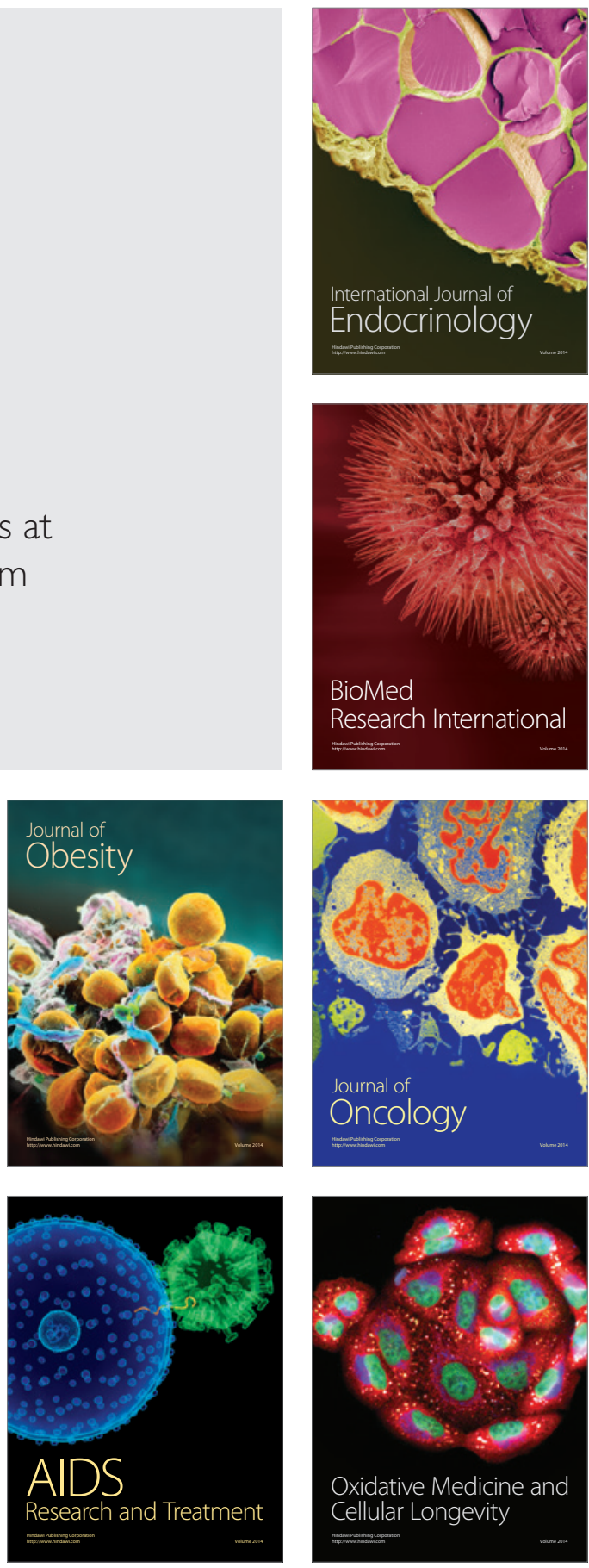